\title{
Congenital Horner's syndrome with iris heterochromia
}

\section{Síndrome de Horner congénito con heterocromía de iris}

\author{
Mercedes Molero-Senosiain*, Liseth Salazar-Quiñones, Irene Camacho-Bosca, Álvaro Corrales-Benítez \\ and Enrique Santos-Bueso \\ Hospital Clínico San Carlos, Madrid, Spain
}

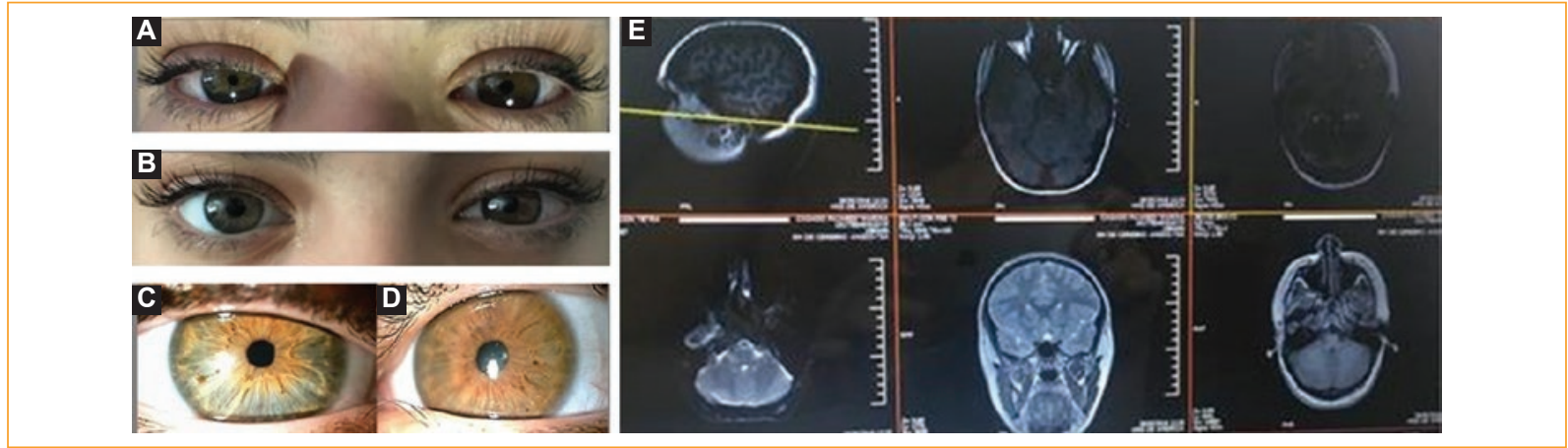

Figura 1. A: Anisocoria with miotic left pupil and left ptosis during examination under scotopic conditions; B: after the administration of apraclonidine hydrochloride (Lopimax $\left.{ }^{\circledR}\right)$, the anisocoria and ptosis persist but now they show reversal, with a mydriatic left pupil; C,D: hHeterochromia iridis by slit lamp examination; E: multiple magnetic resonance imaging sections.

A 20-year-old female who was referred to the neuroophthalmological department due to anisocoria and heterochromia iridis. She was diagnosed with left Horner syndrome due to a vascular malformation at the level of the carotid plexus using nuclear magnetic resonance angiography (NMR angiography).

\section{Conflicts of interest}

The authors declare no conflicts of interest.

\section{Ethical disclosures}

Protection of human and animal subjects. The authors declare that no experiments were performed on humans or animals for this study.
Confidentiality of data. The authors declare that they have followed the guidelines of their work center on the publication of patient data.

Right to privacy and informed consent. The authors have obtained the written informed consent of the patients or subjects mentioned in the article. The corresponding author is in possession of this document.

\section{References}

1. Pardal Souto MJ, Alas Barbeito AB, Taboada Perianes M. Congenital Horner's syndrome. An Pediatr (Barc). 2015;82(5):e213-4.

2. Renard D, Jeanjean L, Labauge P. Heterochromia Iridis in congenital Horner's syndrome. Eur Neurol. 2010;63(4):253.
Available online: 01-11-2019 Rev Mex Oftalmol (Eng). 2019;93(6):303

www.rmo.com.mx 2604-1731/@ 2019 Sociedad Mexicana de Oftalmología. Published by Permanyer México SA de CV. This is an open access article under the CC BY-NC-ND license (http://creativecommons.org/licenses/by-nc-nd/4.0/). 